\title{
SEROLOGICAL REACTIVITY OF OKRA LEAF CURL DISEASE TO AFRICAN CASSAVA MOSAIC VIRUS (ACMV) AND TOMATO YELLOW LEAF CURL VIRUS (TYLCV) ANTISERA IN SUDAN SAVANNA ZONE OF NIGERIA
}

\author{
${ }^{1}$ Zubairu, M. and ${ }^{2}$ Alkali, G. \\ ${ }^{1}$ Department of Agricultural Technology, College of Agriculture, Maiduguri, Borno State, Nigeria. \\ ${ }^{2}$ Department of Crop Protection, Faculty of Agriculture, University of Maiduguri, Borno State, Nigeria. \\ DOI: https://doi.org/10.51193/IJAER.2021.7205
}

\begin{abstract}
A survey was conducted in Maiduguri during the 2016 cropping season to identify the serotypes and distribution of Okra Leaf Curl Disease on okra plants to cover 30 major okra growing areas in Maiduguri. The confirmation of serotypes of the virus was done using African cassava mosaic virus (ACMV) and Tomato Yellow Leaf Curl Virus (TYLCV) antibodies obtained from Deutche Sammlang von Mikroorganism and Zeckulturan (DSMZ) Brauschweig, Germany. The reactivity of 30 different OLCV isolates after tests with antisera with TAS ELISA distinguished four serological profiles; those showed positive reaction with the two antisera were designated as serotype SRP A, the second serological profile included isolates that showed positive reaction with only TYLCV antisera, and were designated as serotypes SRP B, the third serological profile was isolate which showed positive reaction with only ACMV antisera and were designated as serotype $\mathrm{C}$. The fourth serological profile included those isolates which had negative reaction with the two antisera (TYLCV and ACMV), and were designated as serotype SRP D. Based on the results of the study, various serotypes exists and begomovirus occurring on tomato and cassava in neighboring farms also infects okra in Maiduguri. Such information could eventually be utilized in the development of integrated begomovirus management packages in crop rotation, inter cropping and insect vector control. Further new trend of other possible management solutions for begomovirus which are worth trying in developing countries like Nigeria such as knowledge of these serotypes of the virus to provide a sound basis for understanding the present status, distribution and mixed infection structure of begomoviruses in its different hosts across the important okra and other vegetables growing areas in Nigeria.
\end{abstract}


International Journal of Agriculture and Environmental Research

ISSN: 2455-6939

Volume: 07, Issue: 02 "March-April 2021"

Keywords: Okra, Okra Leaf Curl Disease, Tomato Yellow Leaf Curl Disease, Africa Cassava Mosaic Virus, Serotypes

\section{INTRODUCTION}

The wide diversity among begomoviruses associated with mixed infections is supposedly assisting in recombination and false recombination events leading to the frequent emergence of novel begomoviruses, having devastating effect on the okra (Padidam et al, 1999). This recombination has played a significant role in the evolution of Gemini viruses (Seal et al., 2006) including origin of Okra Enation Yellow Leaf Curl virus (OELCuV) as the sequence making up OELCuV have originated from malvaceous begomoviruses; Cotton Leaf Curl Bangaluru Virus (CLCuBaV), Mesta Yellow Vein Mosaic Virus (MeYVMV), and Bhendi Yellow Vein Mosaic Virus (BYVMV) (Venkataravanappa et al., 2015). OELCuD may be caused by OELCuV in association with at least two distinct beta satellite (OLCuB) (Venkataravanappa et al., 2015).This recombination of okra leaf curl beta satellites observed in Hydrabad India showed six major and minor recombination with BYVMV, hot-spots and break points (Sohrab et al., 2015). Such recombination was also observed in southern India where YVMV and OLCV disease of okra show either leaf curl or yellow vein mosaic symptoms, (Sohrab et al., 2013) due to the emergence of new viral strains that results to the recombination and pseudo-recombination.

Serological relationship among different whitefly transmitted geminiviruses do exists that these viruses react with a various MAbs raised against any of the members belonging to the geminiviruses in their identification or differentiation between isolates of the same virus (Alshahwan, 2001). Similar relationship was reported to occur among whitefly transmitted geminiviruses (Sequeira and Harrison, 1982; Cohen et al, 1983; Thomas et al, 1986, Roberts et al, 1984; Hamilton et al, 1984, Howarth et al, 1985; Harrison et al, 1991 and Swanson and Harrison, 1993). Therefore, antisera homologous to one whitefly transmitted geminivirus were used by Roberts et al, (1984); Harrsison et al, (1991) \& Ghanem, (2003) to detect other geminiviruses.

Whitefly transmitted geminiviruses found in tomatoes in different regions have consistently different profiles, whereas those from the same region have similar profile (Harrison et al., 1991; Muniyappa et al, 1991; Macintosh et al, 1992). Hong and Harrison (1995) comparing TYLCV isolates from various countries showed distinction among them by the nucleotide sequence of their coat protein gene. A culture of Cotton Leaf Curl Virus from Pakistan (CLCuV-PK), was transmitted by whiteflies (Bemisia tabacci) to seven plant species, including French bean, okra, tobacco and tomato, and caused vein thickening and leaf curl symptoms in the plants which were readily detected in triple antibody sandwich ELISA (TAS-ELISA) with 11 out of 31 monoclonal 
International Journal of Agriculture and Environmental Research

ISSN: 2455-6939

Volume: 07, Issue: 02 "March-April 2021"

antibodies raised against the particles of three other geminiviruses: African cassava mosaic, Indian cassava mosaic and okra leaf curl viruses. Smaller differences in epitope profile were found among virus isolates from cotton (Gossypium hirsutum) collected from different districts in Pakistan over a 5-year period.

All whitefly transmitted geminiviruses have been found to be serologically related and their interrelationship help in their detection by ELISA (Sequeira and Harrison, 1982; Cohen et al, 1983) with either polyclonal or cross reacting monoclonal antibodies (Thomas et al., 1986). Various geminiviruses have been distinguished by the reactivity in ELISA of individual virus isolates with panels of monoclonal antibodies (MAbs) raised against purified particles of selected whitefly transmitted geminiviruses and having ranges of cross reactivity with heterologous whitefly transmitted geminivirus (Harrison et al, 1991; Swanson and Harrison, 1993). Hence the study therefore aims to establish the serotypes of okra leaf curl geminivirus found in other crops growing in the same agro ecological zones.

\section{MATERIALS AND METHODS}

\section{Field Survey and Sampling}

Field survey were carried out in okra fields to collect okra plants showing symptoms of leaf curl virus during 2016 cropping season at 30 locations around Maiduguri namely; Goni Kakkari, Shuwari 4, Shuwari 3, Shuwari Madinatu, Gonglong Lawanti, Gonglong Kayayya, Old Maiduguri Lambu Area, Old Maiduguri Kasan Yashi, Shuwari Power Station, Shuwari Elmiskin, Farm center, Dusman, Shokari, Alizarmari, Angiudda, Khaddamari, Zabarmari, Bulamatari, Goniri, Fori, Kiriri, Kazallari, Fulatari, Unimaid, Kolori, Molai, Dalori, Gonglong Bulamari, Kazallari and Bale. The excised leaves samples were washed with sterile water dried and then sealed in plastic bags and stored at $-20^{\circ} \mathrm{C}$ until usage.

\section{Determination of Sero-reactivity of Okra Leaf Curl Virus to ACMV and TYLC Antisera}

The triple antibody sandwich enzyme linked immunosorbent assay (TAS ELISA) was performed as described by Clarks and Adams (1977), for the determination of the serotypes of OLCV at the plant virology laboratory, Department of Crop Protection, Ahmadu Bello University, Zaria, Nigeria.

Monoclonal antibodies of Tomato Yellow Leaf Curl Virus (TYLCV) and African Cassava Mosaic Virus (ACMV) were used. The specific antibody was diluted in a coating buffer to give a dilution ratio of 1:1000. $200 \mu 1$ of the solution were added to each well. The microtiter plate was then covered and incubated at $37^{\circ} \mathrm{C}$ for 2 hours. The plates were then washed 3 times with PBS- 
International Journal of Agriculture and Environmental Research

ISSN: 2455-6939

Volume: 07, Issue: 02 "March-April 2021"

Tween using wash bottle and soak for three minutes. The plates were then blot dried by tapping upside down on tissue paper. $200 \mu \mathrm{l}$ of $2 \%$ skim milk in PBS Tween was added to each well and incubated for 30 minutes at $37^{\circ} \mathrm{C}$ for blocking. Thereafter, the plate was inverted and allowed to drain. The samples were then extracted by grinding the leaves in an extraction buffer and $200 \mu 1$ of the aliquots solution was added to each well and the plate was then covered and incubated overnight at $4{ }^{\circ} \mathrm{C}$. The plates were then washed 3 times and blot dried. $200 \mu 1$ of the TYLCV and ACMV MAb were diluted in the ratio of 1:50 conjugate buffer into each well. The plates were then covered and incubated for 2 hours at $37^{\circ} \mathrm{C}$ and washed again three times with PBS-Tween. RAM-AP was then diluted in conjugate buffer in the ratio $1 \mu \mathrm{l}: 1000 \mathrm{ml}$ and $200 \mu 1$ were then added to each well. The plates were then covered and incubated for 1 hour at $37^{\circ} \mathrm{C}$. The plates were washed again 3 times with PBS-Tween and blot dried and $200 \mu$ l aliquots of freshly prepared substrate $(1 \mathrm{mg} / \mathrm{ml})$ of para-nitrophenyl- phosphate in substrate buffer. $200 \mu \mathrm{l}$ of the solution was added to each well and incubated at room temperature for 30 minutes. Colour change were measured with ELISA reader (Spectrophotometer) at absorbance value A.405nm were accepted as positive $(+)$ when the reading was greater than twice the mean absorbance value of the virus free control sample. Any other value below that was considered as negative (-). The positive value were visualized when the colourless substrate p-nitrophynyl phosphate give rise to a yellow p-nitrophenol product.

\section{RESULTS}

\section{Serological profile of okra leaf curl virus isolates collected in Maiduguri}

Four serological profile (SRP) were evident using two monoclonal antibodies (AS 0585, 0546/2) raised against Tomato Yellow Leaf Curl Virus (TYLCV) and (RT 0421-0421/2) raised against African Cassava Mosaic Virus (ACMV).

Table 1 show the reactivity of 30 different OLCV isolates after tests with antisera bodies in TAS ELISA. Those showed positive reaction with the two antisera were designated as serotype SRP A. the second serological profile included isolates that showed positive reaction with only TYLCV antisera, and were designated as serotypes SRP B. the third serological profile was isolate which showed positive reaction with only ACMV antisera and were designated as serotype C. The fourth serological profile included those isolates which had negative reaction with the two antisera antibodies (TYLCV and ACMV), and were designated as serotype SRP D.

Several variants of the serological profiles were distinguished by their unusual reaction with the two antisera. In SRP A, four isolates showed a strong positive reaction with TYLCV and weak positive reaction with ACMV antisera from Shuwari 4, Shuwari madinatu, Kazallari and Dalori. One isolate showed strong positive (TYLCV) and positive reaction (ACMV) with the two 
antisera from Kolori. Similarly, one isolate showed positive reaction (TYLCV) and weak positive reaction (ACMV) from Farm center. Also, one isolate showed weak positive reaction with the two antisera in serotype B from Bale. Three isolates showed strong positive reaction with TYLCV antisera from Shuwari power station, Dusman, Showkari, Alizarmari and Unimaid. Similarly, seven isolates showed weak positive reaction with TYLCV antisera from Goni kakkari, Gonglong lawanti, Bulamari, Goniri, Fori, Kiriri and Molai. In SRP C, one isolate showed weak positive reaction with ACMV antisera from Khaddamari. In serotype SRP D, seven isolates have negative reaction with both TYLCV and ACMV antisera (Table 1).

Table 1: Serological Profile of Okra Leaf Curl Virus Isolates Detected with TAS ELISA Kits DSMZ AS 0588, AS 546/2 against Tomato Yellow Leaf Curl Virus (TYLCV) and DSMZ RT 0421-042/2 against African Cassava Mosaic Virus (ACMV)

\begin{tabular}{lcccc}
\hline Locations & TYLCV & $\begin{array}{c}\text { Absorbance } \\
\text { Category }\end{array}$ & ACMV & $\begin{array}{c}\text { Absorbance } \\
\text { Category }\end{array}$ \\
\hline Gonikakkari & 0.386 & + & 0.254 & - \\
Shuwari 4 & 1.170 & +++ & 0.328 & - \\
Shuwari 3 & 2.637 & +++ & 0.406 & + \\
Shuwarimadinatu & 2.017 & +++ & 0.394 & - \\
Gonglonglawanti & 1.016 & +++ & 0.212 & - \\
Gonglongkayayya & 0.493 & ++ & 0.161 & - \\
Old maid lambu area & 0.250 & - & 0.132 & - \\
Old maid kasan Yashi & 1.026 & +++ & 0.244 & - \\
Shuwari power station & 0.869 & ++ & 0.163 & - \\
Shuwari el miskin & 0.207 & - & 0.256 & - \\
Farm center & 0.763 & ++ & 0.517 & - \\
Dusman & 0.898 & ++ & 0.224 & - \\
Shokari & 0.628 & ++ & 0.183 & - \\
Alizarmari & 0.767 & ++ & 0.234 & - \\
Angudda & 0.246 & - & 0.267 & - \\
Khaddamari & 0.137 & - & 0.460 & - \\
Zabarmari & 0.153 & - & 0.127 & - \\
Bulamatari & 0.556 & + & 0.202 & - \\
Goniri & 0.316 & + & 0.183 & - \\
Fori & 0.452 & + & 0.320 & - \\
Kiriri & 0.327 & + & 0.246 & - \\
Kazallari & 2.004 & 0.332 & + & - \\
Fulatari & + & + & - \\
\hline
\end{tabular}




\begin{tabular}{llccc}
\hline Unimaid & 0.789 & ++ & 0.265 & - \\
Kolori & 2.546 & +++ & 0.753 & ++ \\
Molai & 0.450 & + & 0.331 & - \\
Dalori & 1.408 & +++ & 0.483 & + \\
GongulongBulamari & 0.224 & - & 0.198 & - \\
Kazallari & 0.147 & - & 0.214 & - \\
Bale & 0.348 & + & 0.352 & + \\
PC & $(+)$ & +++ & 0.958 & +++ \\
NC & 0.156 & - & 0.174 & - \\
\hline
\end{tabular}

Strong Positive Reaction $=+++$ Positive Reaction $=++$ Weak Positive Reaction $=+$

Negative Reaction $=-\quad$ PC- positive control $\quad \mathrm{NC}-$ Negative control

\section{DISCUSSION}

The occurrence of the serological diversity of the OLCV isolates assessed with panel of antisera of ACMV and TYLCV in the surveyed farmers field suggested that several serotypes or epitope profile of the virus co-exist in the surveyed areas in Maiduguri. The serological similarities and mixed infection observed between isolates within the same and different locations in the surveyed areas confirm the cross reaction of the antibodies produced against one begomovirus coat protein with other begomoviruses (Nirbbay et al., 2010), its capability of infecting morethan 30 species in over 12 plant families and especially whitefly transmitted begomoviruses were found to be associated with cassava mosaic, tobacco leaf curl, tomato leaf curl, cotton leaf curl and okra leaf curl viruses (Konate et al., 1995 and Makhlouf et al., 2015). Similarly, Venkataravanappa et al., (2014) reported that sequence comparisons of begomovirus from various locations revealed the existence of different isolates in different forms also confirm the great cross infection potential of OLCV disease complexes transmitted under the natural conditions by whitefly vectors. Furthermore, Konate et al., (1994) reported that recombinant or mixed infection forms of begomoviruses may play a role in their diversification and adoption to new hosts and localities, resulting in many species described so far.

This study has proved that most whitefly transmitted begomoviruses are serologically related and distinguished by reactivity of individual virus isolates with panels of monoclonal antibodies raised against one begomovirus (ACMV and TYLCV) and having range of cross reactivity. Viruses occur singularly or in mixtures whereby two viruses detected in one sample. Similar results have been observed by Swanson and Harrison, (1993) that a network of antigenic relationships was revealed by reaction between OLCV antisera and other whitefly transmitted geminiviruses from six plant species in 12 countries. 
International Journal of Agriculture and Environmental Research

ISSN: 2455-6939

Volume: 07, Issue: 02 "March-April 2021"

By using antibodies, it was demonstrated that several whitefly transmitted geminiviruses are serologically related (Roberts et al., 1984). The results of OLCV detection in field samples demonstrated that TYLCV and ACMV differed in their serological reactivity. Konate et al., (1995) observed the cross reactivity of MAbs by TAS-ELISA where they found four epitope profile with the characteristics of ACMV, OLCV, TYLCV and TobLCV. Similar results were found by Swanson and Harrison (1993) who detected all the OLCV isolates from West Africa. ACMV has a narrow spectrum of serological reactivity detecting only 8 serotypes out of 30 isolates with conspicuous symptoms of the virus. This probably implies the existence of fewer ACMV strains in the fields in Maiduguri possibly because cassava is not a key crop in Maiduguri and ACMV, although widely distributed in the middle belts and southern parts of Nigeria does not present such a serious problem in the area probably which was why ACMV was recorded in only few locations compared to TYLCV which was recorded in 23 locations in the surveyed areas. This explains the fact that most of the localities in the surveyed areas grow tomatoe during the dry season which mostly extended into the rainy periods confirm the great cross infection potential of TYLCV compared to ACMV to the okra plants which was usually grown side by side with tomato plants in the localities. These results established that begomoviruses occurring on tomato in the neighboring gardens also infect okra in the study areas. Such information should eventually be utilized in the development of integrated begomovirus disease management packages; such as considering alternative hosts of the virus, mixed cropping in the same field, crop rotation and other possible management solutions for begomovirus cross-infection among its range of hosts which are worth trying in developing countries like Nigeria. Konate et al., (1995) stated that cassava is not widely distributed in Burkina Faso thus did not pose a serious threat. The phenomenom of mixed infection is extremely important for virus evolution because mixed infections are prerequisite for the occurrence of natural recombination events which may contribute to the appearance of new begomovirus, as reported by Venkataravanappa et al., (2013); Padidam et al., (1999) and Sanz et al., (2000) where they found expanding diversities resulting in emergence of new virus strains and their ability to infect new hosts. The serological relationship between ACMV and OLCV in this study also corroborates with the findings of Gahnem, (2003) where he found serological relationship between OLCV-SA, SLCV and TYLCV using 1:100 cross absorbance with ACMVPAB. Also MAbs to TYLCV succeeded to detect the presence of leaf curl virus in diseased tissue of okra plants. Similar results were reported by Makhlouf et al., (2015) figures out that polyclonal antiserum to TYLCV detected OLCV in cotton and okra plants. This is as a result of frequent breakdown of the okra leaf curl viral disease resistance breakdown in okra varieties. This is also in agreement with the findings of Mishra et al, (2017), Sanwal et al., (2014) where they stressed the evolution of new viral strains as the major factors responsible for the breakdown of tolerance in okra varieties. 
International Journal of Agriculture and Environmental Research

ISSN: 2455-6939

Volume: 07, Issue: 02 "March-April 2021"

\section{CONCLUSION}

The sero-distribution of the pathogen in the study area show functional interaction with varying efficiencies possibly leading to new begomovirus recombination and pseudo-recombinants with component from different host crop formed which may overcome plant resistance and increase the host range of the begomoviruses already existing in the study area. This might be why okra in Maiduguri is a host to many begomovirus (TYLCV and ACMV) complexes with uncharacterized variants and/strains. Thus there is an urgent need to come up with further studies on the disease spread, host range as well as molecular characterization of begomovirus to identify the currently circulating OLCV isolates complex as well as possible emergence of new strains with their extended or alternative host characteristics in Maiduguri Sudan Savanna zone of Nigeria.

\section{REFERENCES}

Al-Shahwan, I. M., Abdalla, O. A. and Al-Saleh, M. A. (2001). Tomato Yellow leaf curl virus in Saudi Arabia. Journal of plant diseases and protection. 108 (4), 407-412

Clark, M. F. and Adams. A. N. (1977). Characteristics of the microplate method of enzyme-linked immunosorbent assay for the detection of plant viruses. Journal of General Virology 34: 475-483.

Cohen, S., Duffus, J. E., Larsen, R. C., Liu, H. Y. and Flock, R. A. (1983). Purification, serology and vector relationships of squash leaf curl virus, a whitefly transmitted geminivirus. Phytophatology 73: 1669-1673

Ghanem, G. A. M., (2003). Okra leaf curl virus: A monopartite begomovirus infecting okra crop in Saudi Arabia. Arab Journal of Biotechnology 6(1), 139-152. Pp 55

Harrison, B. D., Muniyappa, V., Swanson, M. M., Roberts, I. M., and Robinson, D. J. (1991). Recognition and differentiation of seven whitefly transmitted geminiviruses from India and their relationship to ACMV and Thailand Mung bean Yellow Mosaic Virus. A. App. Biol. 118: 299-308

Hong, Y. G. and Harrison, B. D. (1995). Nucleotide sequence from tomatoe leaf curl virus from different countries, evidence for three geographically separate branches in evolution of the coat protein of whitefly transmitted geminiviruses. J. Gen. Virol. 76: 2043-2049

Howarth, A. J., Caton, J. Boserf, M. and Goodman, R. M. (1985). Nucleotide sequence of bean golden mosaic virus and a model for gene regulation in geminivirus. Proc. Natl. Acad. Sci. USA. 82: 3572-3576 
International Journal of Agriculture and Environmental Research

ISSN: 2455-6939

Volume: 07, Issue: 02 "March-April 2021"

Konate, G. Barro, N., Fargette, D., Swanson, M. M. and Harrison, B. D. (1995). Occurrence of whitefly transmitted geminiviruses in crops in Burkina Faso, and their serological detection and Differentiation. Ann. App. Biol. 126: 121-129

Macintosh, S., Robinson, D. J. and Harrison, B. D. (1992). Detection of three whitefly transmitted geminiviruses occurring in Europe by tests with heterologous monoclonal antibodies. Annals of Applied Biology. 121: 297-303

Makhlouf, A., Asse, D. G., Hafeez, E. E., and ElSeehy, M. A. (2015). Molecular and Serological studies for detection and identification of Cotton Leaf Curl virus in Cotton Plant (G. barbadense L.) in Egypt. British microbiology research journal. 9(3): 1-9

Mishara G. P., Singh, B., Seth, T., Singh, A. K., Halder, J., Krishnan, N., Tiwari, S. K., and Singh,P.M.(2017). BiotechnolologicalAdvancements and Begomovirus management in Okra (Abelmoschus esculentus L.): status and perspectives. Frontiers in Plant science. $8: 360$

Muniyappa, V. Swanson, M. M., Duncan, G. H. and Harrison, B. D. (1991). Particle purification, properties and epitope variability of Indian tomato leaf curl geminivirus. A. App. Biol. 118: 595-604

Nirbbay, K., Achut, K. S., Brutati, C. and Supriya, C. (2010). Recent Advances in Geminivirus detection and Future perspectives. Journal of Plant Protection Sciences, 2(1) 1-18.

Padidam, M., Sawyer, S., and Fauquet, C. M. (1999). Possible emergenceof new geminiviruses by frequent recombination. Virology265, 218-225.

Roberts, I. M., Robbinson, D. G. and Harrison, B. D. (1984). Serological relationships and genome homologies among geminivirus. J. Gen. Virol. 65: 1723-1730

Sanwal, S. K., Singh,M., Singh, B., and Naik, P. S. (2014). Resistance to yellow vein mosaic virus and okra enation leaf curl virus: challenges and future strategies. Curr. Sci. 106, $470-1471$.

Seal, S. E., Bosch, F. V. D., and Jeger,M. J.(2006). Factors influencing begomovirus evolution and their increasing global significance: implications for sustainable control. Crit. Rev. Plant Sci. 25, 23-46.

Sequeira, J. C, and Harrison, B. D. (1982). Serological studies on cassava latent virus. Annals of Applied Biology 101: 33-42

Sohrab, S. S., Mirza, Z., Karim, S., Rana, D., Abuzenadah, A. M.,Chaudhary, A. G., et al. (2013). Detection of begomovirus associated with okra leaf curl disease. Arch. Phytopathol. Plant Prot. 46, 1047-1053. 
Sohrab, S. S., Yasir, M., El-Kafrawy, S. A., Mirza, Z., AlZahrani, H. S. M., Bhattacharya, P., et al. (2015). Recombination analysis and in silico structural characterization of ${ }_{\beta} \mathrm{C} 1$ protein gene from Okra leaf curl betasatellite. Plant Omics J. 8, 565-571.

Swanson, M.M., Harrison, B.D., (1993). Serological relationship and epitope profiles of an isolate of Okra leaf curl germinivirus from Africa and the Middle East. Biochemie 75, 707-711.

Venkataravanappa, V., Reddy, C. N. L., Jalali, S., and Reddy, M. K. (2013). Molecular characterization of a new species of begomovirus associated with yellow vein mosaic of bhendi (okra) in Bhubhaneswar, India. Eur. J. Plant Pathol. 136, 811-822.

Venkataravanappa, V., Prasanna, H. C., Reddy, C. N. L., and Reddy, M. K. (2014). Evidence for two predominant viral lineages, recombination and subpopulation structure in begomoviruses associated with yellow vein mosaic disease of okra in India. Plant Pathol. 64, 508-518.

Venkataravanappa, V., Reddy, C. N. L., Jalali, S., Briddon, R. W., and Reddy, M. K. (2015). Molecular identification and biological characterization of a begomovirus associated with okra enation leaf curl disease in India. Eur. J. Plant Pathol. 141, 217-235. 